\title{
Enhancing Furnace Thermal Efficiency by Adjusting Fuel Temperature
}

\author{
Chien-Li Lee ${ }^{1} \&$ Chih-Ju G. Jou ${ }^{2}$ \\ ${ }^{1}$ Research and Development Center for Water Resource and Conservation, National Kaohsiung First University \\ of Science and Technology, Taiwan \\ ${ }^{2}$ Department of Safety, Health and Environmental Engineering, National Kaohsiung First University of Science \\ and Technology, Taiwan \\ Correspondence: Chih-Ju G. Jou, Juoyue Road, Nantsu District, Kaohsiung 811, Taiwan. Tel: 886-7-601-1000 \\ ext. 2316. E-mail: george@ccms.nkfust.edu.tw
}

Received: March 18, 2013 Accepted: May 22, 2013 Online Published: June 17, 2013

doi:10.5539/eer.v3n2p1 URL: http://dx.doi.org/10.5539/eer.v3n2p1

\begin{abstract}
Increasing fuel temperature leads to lower fuel density so that speed of the fuel leaving the nozzle increases causing the fuel to reach the burning point sooner. Hence, a higher temperature can be maintained in the furnace to reduce heat loss. Increasing the fuel temperature also causes higher temperature of the hot gas surrounding the burner nozzle, faster flowing velocity for the hot gas flow in the furnace, more even thermal distribution in the furnace, as well as faster thermal flow rising velocity and higher temperature in the furnace radiation zone. Hence, the fuel consumption and carbon dioxide emission are significantly reduced. In this study, results obtained with a full-scale furnace show that when the fuel temperature is raised from $95^{\circ} \mathrm{C}$ to $130^{\circ} \mathrm{C}$, the hot gas temperature in the convective zone of the furnace rises by $21{ }^{\circ} \mathrm{C}$; the furnace pressure increases by $2.5 \mathrm{~mm} \mathrm{H}_{2} \mathrm{O}$ so that oxygen concentration in the excess air drops by $1.2 \mathrm{vol} \%$. Under these conditions, $7.5 \times 10^{5} \mathrm{~m}^{3}$ of fuel cost can be saved, and 858 ton per year of $\mathrm{CO}_{2}$ emission can be reduced.
\end{abstract}

Keywords: fuel temperature, carbon dioxide, thermal furnace

\section{Introduction}

Increasing fuel demands as a result of booming global economy (Yang, Wang, Zhou, \& Liu, 2012) leads to gradual depletion of petroleum fuel in addition to causing global warming problem (Pitt, Randolph, Jean, \& Chang, 2012). Raising the thermal efficiency for furnaces burning petroleum fuel (Zhang, Wang \& Zhang, 2012), improving the incineration efficiency (Flamme, 2001), and recovering energy from waste heat and waste gas become the most pertinent strategies before an alternative energy source can be realistically developed (Kimemia \& Annegarn, 2012).

Many advanced industrial nations have carried out research to develop new or improved technologies for improving the thermal efficiency of industrial heat exchanger, boiler and furnace (Lunghi \& Burzacca, 2004). Some of these technologies include adjusting the furnace vacuum, recovering hot exhaust gases, regulating the residual oxygen concentration in excess air, and developing alternative energy. For example, Lee and Jou used the heat recovered from the flue gas to raise temperature of the pre-heated air for reducing the thermal loss and raising the furnace efficiency to save fuel consumption (Lee \& Jou, 2011). Lee and Jou reduced the oxygen concentration in the flue excess air for raising the thermal efficiency of boiler and furnace to reduce fuel consumption and carbon dioxide emission (Lee \& Jou, 2012); Lee, Jou, Tsai and Wang (2007); Jou, Lee, Tsai and Wang (2008); Jou et al. (2010) applied the recovered tail gas from petrochemical processes as an alternative fuel to replace natural gas and diesel fuel to power a full-size furnace as well as a steam-gas cogeneration high-pressure boiler and furnace, the results show that using the recovered tail gas has the potential of saving fuel cost and reducing carbon dioxide emission.

The fuel composition influences the flame appearance significantly (Ko, Hou, \& Lin, 2003). For example, Choudhuri and Gollahalli (Choudhuria \& Gollahalli, 2003) added various portions of natural gas and propane fuel to hydrogen gas for studying variations of the resulting flame appearance. The results show that at fixed Reynolds number, the hydrogen flame length increases but the flame width decreases with more natural gas or 
propane in the fuel. Additionally, the hydrogen-propane mixture has longer flame length than the hydrogen gas fuel. The hydrogen gas flame is bright orange in color from the flame center to the far burning region with blue and slight reddish color near the front of burner tip. In contrast, the hydrogen-propane flame has the same bright organic color from the flame center to the far burning region; but it is slightly shorter with reddish color near the front of the burner tip. The change in flame appearance is caused by higher $\mathrm{C} / \mathrm{H}$ ratio in propane that leads to the formation of ashy smoke to result in more flame formation and oxidation.

There is little information published in literature concerning the influence of fuel oil temperature on the overall furnace thermal efficiency. In this study, the PSA (Pressure swing adsorption) method is used to recover hydrogen gas from the tail gas emitted from the hydrogen producing process. The recovered hydrogen gas is reused as a fuel additive to power a full-scale distillation unit furnace for studying on-site the influence of fuel temperature on the furnace cost-effectiveness.

\section{Experimental Equipment and Methods}

\subsection{Equipment}

The experimental equipment is a set of heating furnace used in the distillation operation (Figure 1) (Petro-Chen Development Co. Inc., 1993). The furnace set consists of two identical furnaces with dimensions of $11.4 \mathrm{~m}$ in length, $5.0 \mathrm{~m}$ in width and $10.0 \mathrm{~m}$ in height. It is equipped with 14 burners with a total of 28 burners that have a total rated heat releasing capacity of $68.15 \mathrm{~mm} \mathrm{kcal} / \mathrm{hr}(\mathrm{LHV})$. Both furnaces are capable of burning fuel oil as well as mixture of gas and No. 6 fuel that contains (wt $\%)$ 86.03\% C, $12.5 \% \mathrm{H}, 0.5 \% \mathrm{~S}, 0.35 \% \mathrm{~N}, 0.625 \% \mathrm{O}$, and $0.05 \%$ ash is used. The average hydrocarbon components include (in volume) $64.2 \mathrm{~mole} \% \mathrm{H}_{2}, 11.1 \mathrm{~mole}_{0} \mathrm{CH}_{4}$, 8.4 mole $\% \mathrm{C}_{2} \mathrm{H}_{6}, 0.4$ mole $\% \mathrm{C}_{2} \mathrm{H}_{4}, 6.0$ mole $\% \mathrm{C}_{3} \mathrm{H}_{8}, 0.2$ mole $\% \mathrm{C}_{3} \mathrm{H}_{6}, 1.5$ mole $\%$ n- $\mathrm{C}_{4}^{+}, 1.8$ mole $\% \mathrm{i}_{-} \mathrm{C}_{4}{ }^{+}, 0.7$ mole $\% \mathrm{i}_{-} \mathrm{C}_{5}^{+}, 0.3 \mathrm{n}-\mathrm{C}_{5}{ }^{+}$, and 0.7 mole $\% \mathrm{n}_{-} \mathrm{C}_{6}{ }^{+}$.

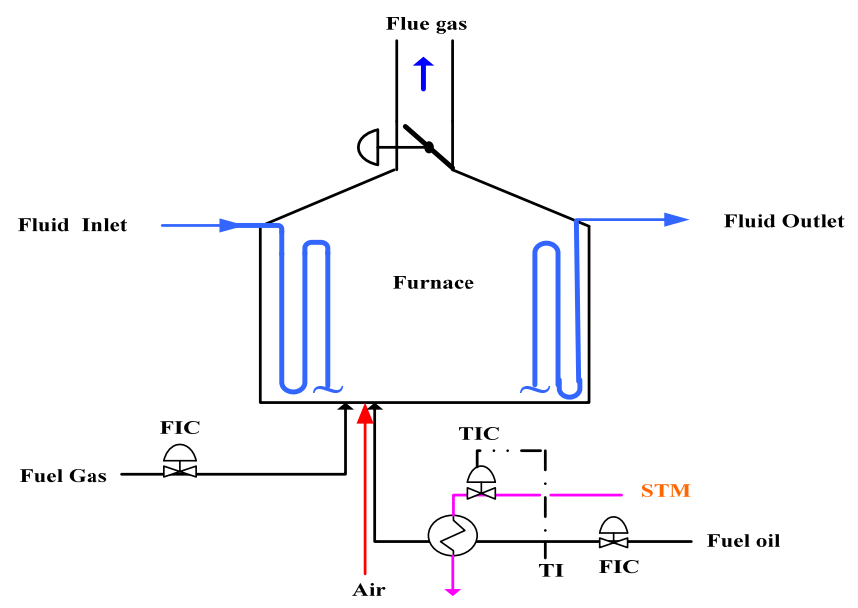

Figure 1. Schematic diagram of the furnace system

\subsection{Methods and Analyses}

This study was conducted by using the ACC (Automatic Combustion Control) system to operate the furnace. The temperature of the pre-heated gas prior to entering the furnace was used as a control parameter; it was maintained constant at $330{ }^{\circ} \mathrm{C}$. During the experiment, the exit temperature of fuel gas and pre-heated gas mixture was controlled by adjusting the fuel input in response to variations of the calculated exit temperature. Fuel oil (FO) and fuel gas (FG) have different heat values; $1.3 \mathrm{~m}^{3}$ of FG generate the same heat as $1 \mathrm{~m}^{3}$ of FO; and the volumetric flow rate of fuel is calculated by multiplying the percentage of opening for control value by the maximum value volumetric flow rate and then by the ratio of fuel heat value.

The furnace was loaded $100 \%$ during the study period with air baffle and flue damper maintained at the same degrees of opening. The fuel temperature that was raised by the low pressure steam through a heat exchanger was gradually increased from $95{ }^{\circ} \mathrm{C}$ to $100{ }^{\circ} \mathrm{C}, 105{ }^{\circ} \mathrm{C}, 110{ }^{\circ} \mathrm{C}, 115{ }^{\circ} \mathrm{C}, 120{ }^{\circ} \mathrm{C}, 125{ }^{\circ} \mathrm{C}$ and ultimate to $130{ }^{\circ} \mathrm{C}$ by controlling the temperature control valve for investigating the influence of fuel temperature on the overall furnace thermal efficiency. When the system operation reaches steady-state after each adjustment of fuel temperature, duplicate operational data were recorded every minute for 4 hours and repeat the secondary. The $\mathrm{O}_{2}$ concentration was continuously monitored on-line with CEMS (Continuing Emission Monitor System, E.S.A., 
MIR 900); it has 5.9\% relative accuracy and 0.67 confidence coefficient with $\pm 2{ }^{\circ} \mathrm{C}$ temperature error. The monitoring system was calibrated every six months according to the standard procedures in NIEA A442.70C. Temperature was measured using a thermocouple (K-Type, error is $0.3 \%$ of full scale); pressure was measured using Bourdon Tube with $0.3 \%$ error of the full scale (Ashcroft Co.). The control value is a gate value (Fisher Co.) with an error of $0.3 \%$ when it opens fully.

\section{Results and Discussion}

\subsection{Relationship between the Convection Region Temperature and Furnace Vacuum}

Raising the fuel temperature causes the fuel density to decrease. If the fuel flow rate is maintained unchanged, the fuel flow velocity must be increased. The higher speed for fuel exiting the burner nozzle shortens the time for the fuel to reach the burning point so that the flame volume is reduced. This causes higher temperature and longer residence time for the hot gas flowing in the furnace so that the heat can be evenly distributed in the furnace radiation zone. The rapid rise of the thermal flow from the furnace radiation zone to the convection zone raises temperature of the furnace convection zone. Results shown in Figure 2 indicate the tendency of rising temperature in the furnace convection zone. If the fuel temperature is raised from $95{ }^{\circ} \mathrm{C}$ to $130{ }^{\circ} \mathrm{C}$, the furnace convection zone temperature increases from $674{ }^{\circ} \mathrm{C}$ to $695{ }^{\circ} \mathrm{C}$. On the other hand, if openings for fresh air baffle and flue gas damper unchanged when raising the fuel temperature is raised from $95{ }^{\circ} \mathrm{C}$ to $130{ }^{\circ} \mathrm{C}$, Figure 3 shows that the furnace pressure increases from -6.8 to $-4.3 \mathrm{~mm} \mathrm{H}_{2} \mathrm{O}$.

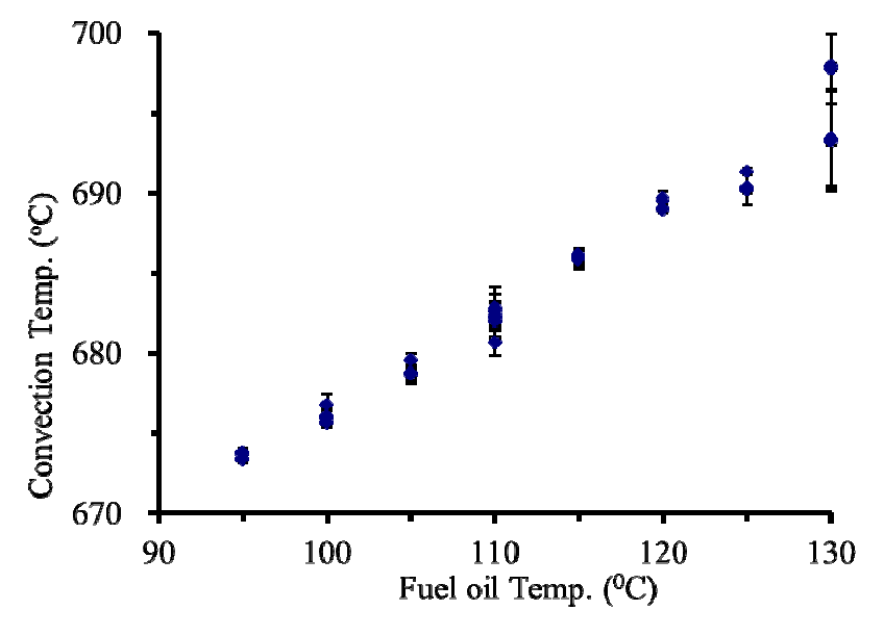

Figure 2. Relationship between fuel temperature and furnace convection zone temperature

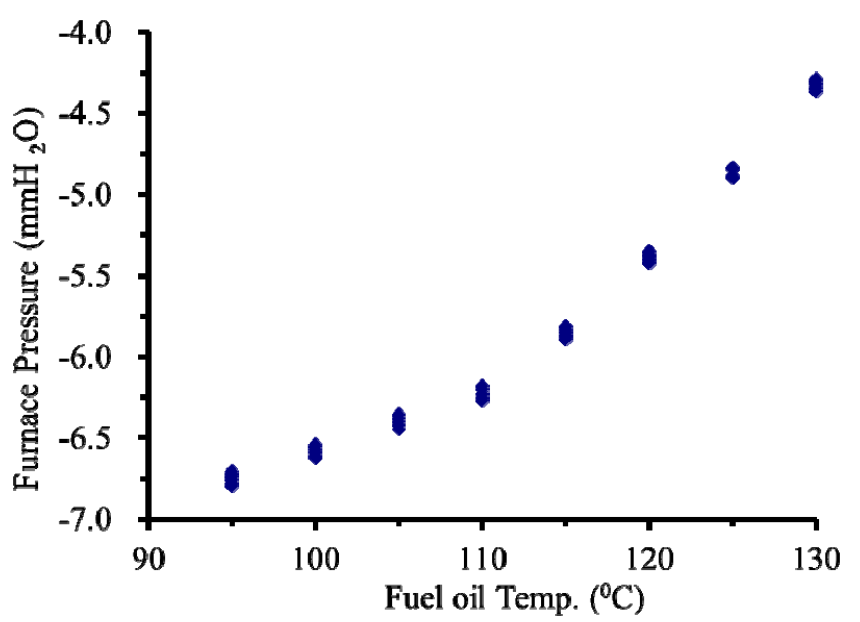

Figure 3. Relationship between fuel temperature and furnace pressure 


\subsection{Influence of Fuel Temperature on Oxygen Concentration in Flue Gas}

As shown in Figure 3, when the fuel temperature is raised from $95{ }^{\circ} \mathrm{C}$ to $130{ }^{\circ} \mathrm{C}$, the furnace internal pressure increases from -6.8 to $-4.3 \mathrm{~mm} \mathrm{H}_{2} \mathrm{O}$. The higher furnace pressure prolongs the residence time for the heat energy staying in the furnace radiation zone. Additionally, results shown in Figure 2 reveal that higher furnace internal pressure causes the furnace convection zone temperature to increase from $674{ }^{\circ} \mathrm{C}$ to $695{ }^{\circ} \mathrm{C}$. Hence, when mixture of air and fuel is used, and the furnace is subject to higher temperature, the oxygen concentration in the uprising hot gas flow is lowered causing a decreasing tendency of $\mathrm{O}_{2}$ concentration in the flue gas (Figure 4). The oxygen concentration in the flue gas drops from $3.2 \mathrm{vol} \%$ to $2.9 \mathrm{vol} \%$ when the fuel temperature is raised from 95 to $105^{\circ} \mathrm{C}$; it further drops to $2.6 \mathrm{vol} \%$ and $2.0 \mathrm{vol} \%$ if the fuel temperature is increased to $115^{\circ} \mathrm{C}$ and $130^{\circ} \mathrm{C}$, respectively.

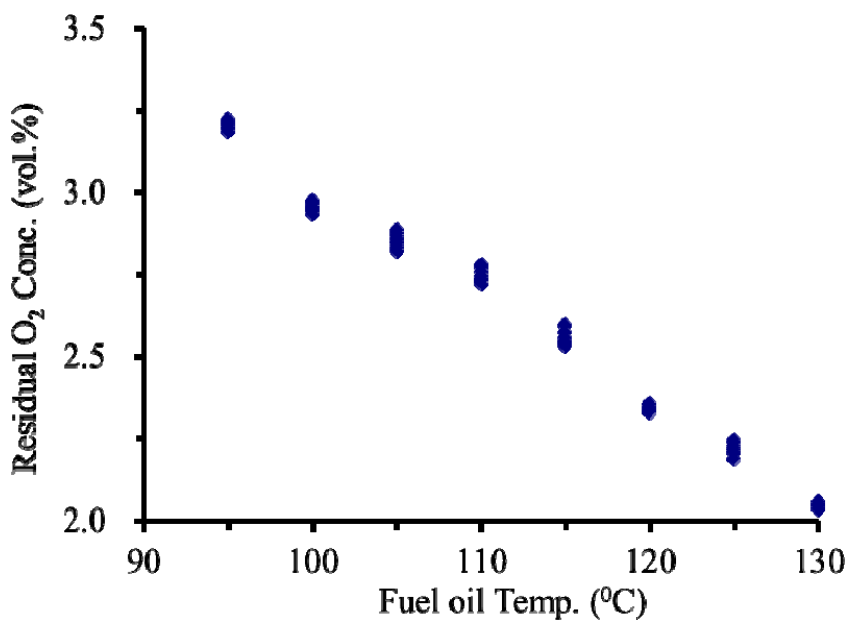

Figure 4. Relationship between fuel temperature and oxygen concentration in the flue gas

\subsection{Influence of Fuel Temperature on Fuel Flow Rate}

Lower oxygen concentration in the excess air indicates higher furnace burning chamber temperature. The higher temperature causes more efficient transfer of thermal energy across the furnace metal wall to raise the conductive thermal flow across the metal furnace wall and hot fluid pipe leading to a higher furnace heat absorbance efficiency. Additionally, when the hot gas stream in the furnace has higher temperature, the time for the fuel to reach the burning point is shortened thus the furnace energy consumption can be reduced. Results shown in Figure 5 indicate that the quantity of fuel consusmed in the furnace has a decreasing tendency with increasing fuel temperature. When the fuel temperature is maintained at $95{ }^{\circ} \mathrm{C}$, the fuel gas flow rate is $1183 \mathrm{~m}^{3} / \mathrm{h}$. Increasing the fuel temperature to $105^{\circ} \mathrm{C}, 115{ }^{\circ} \mathrm{C}$, and $130{ }^{\circ} \mathrm{C}$ causes the gaseous fuel flow rate to drop to 1161 $\mathrm{m}^{3} / \mathrm{h}, 1145 \mathrm{~m}^{3} / \mathrm{h}$ and $1098 \mathrm{~m}^{3} / \mathrm{h}$, respectively. Therefore, maintaining the fuel temperature at $130{ }^{\circ} \mathrm{C}$ will save 7.5 $\times 10^{5} \mathrm{~m}^{3}$ of fuel consumption and reduce 858 tons per year of $\mathrm{CO}_{2}$ emission.

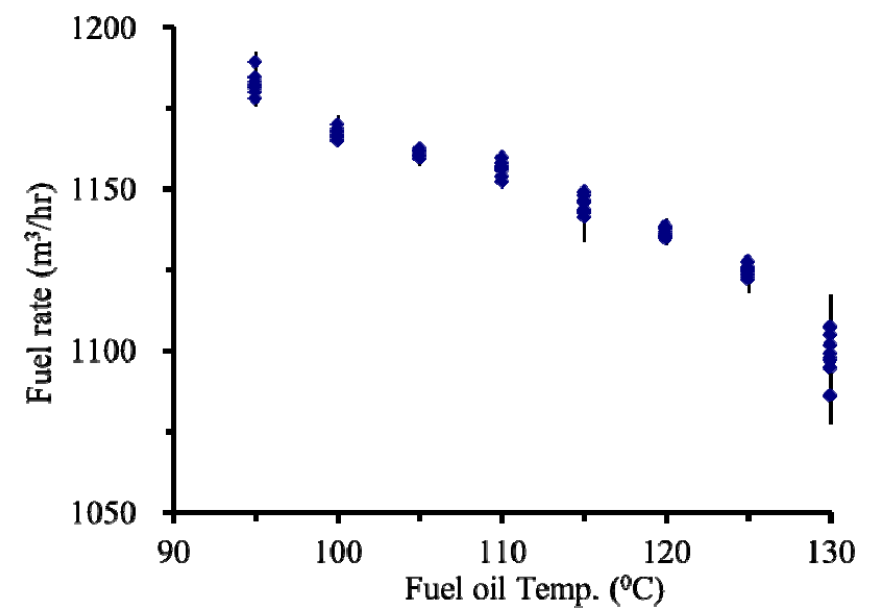

Figure 5. Relationship between fuel temperature and the burning gas fuel flow rate 


\section{Conclusion}

The heat generated in a furnace is transferred via radiation from the fuel burning chamber to the thermal fluid confined in the thermal flow pipe so that the heat is carried away to achieve the objective of hating. Higher fuel temperatures causes the fuel density to drop so that the fuel emitting speed leaving the burner increases leading to shorter time for the fuel to reach the burning point, higher temperature in the burning chamber and less thermal loss. In the study, when the fuel temperature is gradually raised from $95{ }^{\circ} \mathrm{C}$ to $130{ }^{\circ} \mathrm{C}$, on-site results obtained with a currently operated full-scale furnace show that the raised fuel temperature causes the temperature of the furnace convection zone to increase from $674{ }^{\circ} \mathrm{C}$ to $695^{\circ} \mathrm{C}$, furnace pressure to rise from $-6.8 \mathrm{~mm} \mathrm{H}_{2} \mathrm{O}$ to $-4.3 \mathrm{~mm} \mathrm{H}_{2} \mathrm{O}, \mathrm{O}_{2}$ concentration in the flue gas to drop from 3.2 vol.\% to 2.0 vol.\%. Because higher temperature in the burning chamber causes lower oxygen concentration in the excess air, more heat is obviously absorbed and carried away by the thermal flow from the furnace. Additionally, when the hot gas flow in the furnace is under higher temperature, the time for the fuel to reach the burning point becomes shorter so that less fuel is consumed. If the fuel temperature is increased from $95^{\circ} \mathrm{C}$ to $130^{\circ} \mathrm{C}$, the fuel consumption is reduced by $85 \mathrm{~m}^{3} / \mathrm{h}$ with $7.5 \times$ $10^{5} \mathrm{~m}^{3} / \mathrm{yr}$ of fuel saved and 858 tons per year of $\mathrm{CO}_{2}$ reduced.

\section{References}

Choudhuria, A. R., \& Gollahalli, S. R. (2003). Characteristics of hydrogen-hydrocarbon composite fuel turbulent jet flames. International Journal of Hydrogen Energy, 28, 445-454. http://dx.doi.org/10.1016/S0360-3199(02)00063-0

Flamme, M. (2001). Low NOx combustion technologies for high temperature application. Energy conversion and management, 42, 1919-1935. http://dx.doi.org/10.1016/S0196-8904(01)00051-6

Hainsworth, D., Pourkashanian, M., Richardson, P., Rupp, J. L., \& Williams, A. (1995). The Influence of Carbon Dioxide on Smoke Formation and Stability in Methane-Oxgyen-Carbon Dioxide Flames. Fuel, 75, 393-396. http://dx.doi.org/10.1016/0016-2361(95)00265-0

Jou, C. J. G., Lee, C. L., Tsai, C. H., \& Wang, H. P. (2008). Reduction of energy cost and $\mathrm{CO}_{2}$ emission for the boilers in a full-scale refinery plant by adding waste hydrogen-rich fuel gas. Energy and Fuels, 22, 564-569. http://dx.doi:10.1021/ef070180z

Jou, C. J. G., Lee, C. L., Tsai, C. H., Wang, H. P., \& Lin, M. L. (2008). Enhancing the performance of a high-pressure cogeneration boiler with waste hydrogen-rich fuel. International Journal of Hydrogen Energy, 33, 5806-5810. http://dx.doi.org/10.1016/j.ijhydene.2008.05.114

Jou, C. J. G., Wu, C. R., \& Lee, C. L. (2010). Reduction of Energy Cost and $\mathrm{CO}_{2}$ Emission for the Furnace Using

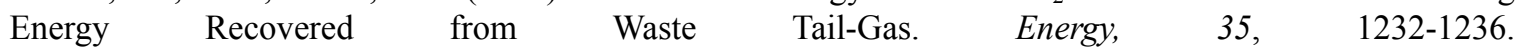
http://dx.doi.org/10.1016/j.energy.2009.11.002

Kimemia, D. K., \& Annegarn, H. J. (2012). Productive Uses of Basic Energy and Fuel Transitions in Urban South Africa. Energy and Environment Research, 2, 103-112. http://dx.doi.org/10.5539/eer.v2n2p103

Ko, Y. C., Hou, S. S., \& Lin, T. H. (2003). Incineration of oil gas at various compositions and supply rates. Proceedings of 14th International Symposium on Transport Phenomena, pp. 445-449.

Lee, C. L., \& Jou, C. J. G. (2011). Saving Fuel Consumption and Reducing Pollution Emissions for Industrial Furnace. Fuel Processing Technology, 92, 2335-2340. http://trove.nla.gov.au/version/172679177

Lee, C. L., \& Jou, C. J. G. (2012). Improving Furnace and Boiler Cost-Effectiveness and $\mathrm{CO}_{2}$ Emission by Adjusting Excess Air. Environ Progress, 31, 157-163. http:// dx.doi.org/10.1002/ep.10543

Lee, C. L., Jou, C. J. G., Tsai, C. H., \& Wang, H. P. (2007). Improvement of a medium-pressure-boiler performance through adjustments on the hydrogen-rich fuel for refinery plant. Fuel, 86, 625-631. http://dx.doi:10.1016/j.fuel.2006.09.001

Lunghi, P., \& Burzacca, R. (2004). Energy recovery from industrial waste of a confectionery plant by means of BIGFC plant. Energy, 29, 2601-2617. http://dx.doi.org/10.1016/j.energy.2004.05.016

Pitt, D., Randolph, J., Jean, D. S., \& Chang, M. (2012). Estimating Potential Community-wide Energy and Greenhouse Gas Emissions Savings from Residential Energy Retrofits. Energy and Environment Research, 2, 44-61. http://dx.doi.org/10.5539/eer.v2n1p44

Yang, G., Wang, H., Zhou, J., \& Liu, X. (2012). Analyzing and Predicting the Economic Growth, Energy Consumption and $\mathrm{CO} 2$ Emissions in Shanghai. Energy and Environment Research, 2, 83-91. http://dx.doi.org/10.5539/eer.v2n2p83 
Zhang, S., Wang, S., \& Zhang, R. (2012). Analysis on the Potential of Greenhouse Gas Emission Reduction in Henan's Electricity Sector. Energy and Environment Research, 2, 195-204. http://dx.doi.org/10.5539/eer.v2n1p195

\section{Copyrights}

Copyright for this article is retained by the author(s), with first publication rights granted to the journal.

This is an open-access article distributed under the terms and conditions of the Creative Commons Attribution license (http://creativecommons.org/licenses/by/3.0/). 